$$
\text { Dis/se/45010-4 }
$$

\title{
CHARACTERIZATION OF ELECTRICALLY
}

\section{CONDUCTING OXIDES}

\author{
Dr. H. U. Anderson, Principal Investigator \\ Ceramic Engineering
}

Dr. D. M. Sparlin, Co-P.I.

Department of Physics.

University of Missouri-Rolla

Rolla, Missouri 65401

- Period -

(January 16, 1989 - December 31, 1989)

\section{DISCLAIMER}

This report was prepared as an account of work sponsored by an agency of the United States Government. Neither the United States Government nor any agency thereof, nor any of their employees, inakes any warranty, express or implied, or assumes any legal liability or responsibility for the accuracy, completeness, or usefulness of any information, apparatus, product, or process disciosed, or represents that its use would not infringe privately owned rights. Reference herein to any specific commercial product, nrocess, or service by trade name, trademark, manufacturer, or otherwise does not necessarily constitute or imply its endorsement, recommendation, or favoring by the United States Government or any agency thereof. The views and opinions of authors expressed herein do not necessarily state or reflect those of the
United States Government or any agency thereof. 


\section{HIGHLAGHTS OF PROGRAM}

(JULY 1, 1988 - DECEMBER 31, 1989)

(1) The studies of the $\mathrm{Ba}_{2} \mathrm{YCu}_{3} \mathrm{O}_{7-\mathrm{x}}$ system have shown that the conduction processes (meiallic or small polaron) have little temperature dependence and are almost entirely a function of oxygen stoichiometry. The ability to achieve superconductivity is so dependent on oxygen stoichiometry that it is not possible to process this oxide and obtain superconductivity without subsequent oxygen anneals in the 400 to $700^{\circ} \mathrm{C}$ temperature range.

(2) The substitution of 10 to $20 \mathrm{~m} \% \mathrm{Ca}$ and $\mathrm{Co}$ into $\mathrm{LaCrO}_{3}$ has enabled the system to be sintered to $>95 \% \mathrm{TD}$ at $1400^{\circ} \mathrm{C}$ without deterioration of either the electrical conductivity or high temperature stability of the resulting dense ceramics. These sinterable $\mathrm{LaCrO}_{3}$ based oxides have immediate applications as solid oxide fuel cell (SOFC) cathodes and interconnects. These studies have now been transferred to SOFC programs sponsored by DOE-Morgantown Energy Technology Center and Ceramatec, Inc.

(3) An elucidation of the structure of the high temperature $\left(1400^{\circ} \mathrm{C}\right)$ phases of $\mathrm{La}$ substituted $\mathrm{SrTiO}_{3}$ has demonstrated our abilities to determine small changes in structure as well as to determine cation defect concentrations using $\mathrm{X}$-ray powder diffraction methods. In this study we were able to show that the oxidized state of $\mathrm{Sr}_{1-\mathrm{x}} \mathrm{La}_{\mathrm{x}} \mathrm{TiO}_{3}$ contained cation vacancies. This is the first direct evidence regarding defect structure of this system.

(4) The studies in the $\mathrm{Y}_{1-\mathrm{x}} \mathrm{Ca}_{\mathrm{x}} \mathrm{CrO}_{3}$ system also are yielding some important results. They are showing that this oxide system is more stable towards reduction than $\mathrm{LaCrO}_{3}$. This suggests that we may have an alternate to $\mathrm{LaCrO}_{3}$ as a high temperature electrode.

(5) The construction of dual high temperature controlled atmosphere dilatometer has been completed. The apparatus is now being used to study the expansion and contraction that occurs - in perovskite oxides as oxygen is absorbed or evolved.

(6) An effective-medium theory of hopping transport in binary systems is explaining the conductivity changes that occur when $\mathrm{Mn}$ is substituted into $\mathrm{LaCrO}_{3}$. It appears that this theory will also apply to the $\mathrm{LaCrO}_{3}-\mathrm{LaCoO}_{3}$ system. 


\section{WORK IN PROGRESS}

The stability of the $\mathrm{Y}_{1-\mathrm{x}} \mathrm{Ca}_{\mathrm{x}} \mathrm{CrO}_{3}$ has caused us to expand our work in the $\mathrm{YCrO}_{3}$ $\mathrm{YMnO}_{3}-\mathrm{YCOO}_{3}$ system. The success of the use of effective medium theory to explain the conduction in $\mathrm{La}(\mathrm{Cr}, \mathrm{Mn}) \mathrm{O}_{3}$ is encouraging us to apply the theory to other systems (such as $(\mathrm{La}, \mathrm{Ca})(\mathrm{Cr}, \mathrm{Co}) \mathrm{O}_{3}$ and $\mathrm{Y}(\mathrm{Cr}, \mathrm{Mn}) \mathrm{O}_{3}$ which behave similarly.

The models that we have proposed to explain the redox behavior of $\mathrm{LaCrO}_{3}, \mathrm{LaMnO}_{3}$, $\mathrm{YCrO}_{3}, \mathrm{BaTiO}_{3}$ and $\mathrm{SrTiO}_{3}$ have oxygen activity and temperature regimes in them where ionic compensation becomes important in the electrical neutrality conditions. In these regions we expect to see considerable ionic transport. In an effort to confirm this we are doing experiments with which we are measuring the ionic transport number by galvanic cell techniques. Our early data suggests that mixed conductivity is occurring in these critical regions. Such information is becoming very important for catalysis, solid oxide fuel cell electrode and oxygen pump applications. We are therefore expanding this work with the intent of defining the regions of mixed conductivity. 


\section{MANUSCRIPTS PUBLISHED OR ACCEPTED FOR PUBLICATION}

R. Koc, H. U. Anderson and S. A. Howard, "Structural, Sintering and Electrical Properties of the Perovskite $(\mathrm{La}, \mathrm{Sr})(\mathrm{Cr}, \mathrm{Mn}) \mathrm{O}_{3} "$, 1st International Symposium, Elec. Chem. Soc.

H. U. Anderson, J. H. Kuo and D. M. Sparlin, "Review of Defect Chemistry of $\mathrm{LaMnO}_{3}$ and $\mathrm{LaCrO}_{3}$ ", 1st International Symposium, Elec. Chem. Soc.

S. Srilomsak, D. P. Schilling and H. U. Anderson, "Thermal Expansion Studies on Cathode and Interconnect Oxides", 1st International Symposium, Elec. Chem. Soc.

J. H. Kuo, H. U. Anderson and D. M. Sparlin, "Oxidation-Reduction Behavior of Undoped and Sr-Doped $\mathrm{LaMnO}_{3}$ Nonstoichiometry and Defect Structure", J. of Solid State Chem., 83. pp. $52-60$ (1989).

C. J. Yu, H. U. Anderson and D. M. Sparlin, "High-Temperature Defect Structure of Nb-

Doped $\mathrm{LaCrO}_{3}$ ", J. of Solid State Chem., 78, pp. 242-249, (1989).

S. A. Howard, J. K. Yau and H. U. Anderson, "Structural Characteristics of $\mathrm{Sr}_{1-\mathrm{x}} \mathrm{La}_{\mathrm{x}} \mathrm{TiO}_{3+\delta}$ as a Function of Oxygen Partial Pressure at $1400^{\circ} \mathrm{C}^{\prime \prime}$, J. of Appl. Phy., Vol. 65, No. (4), pp. 1492-1498, Feb. 1989.

R. F. Huang and H. U. Anderson, "Effect of Volatilization on the Conduction Behavior of Acceptor-Doped Chromium Oxiden, J. Am. Cer. Soc., 72 (8), pp. 1382-85, (1989).

C. C. Chen and H. U. Anuerson, "Synthesis of $\mathrm{YbA}_{2} \mathrm{Cu}_{3} \mathrm{O}_{7-\mathrm{x}}$ Superconductor by the Ethylenc Diamine Process", Industry-University Advanced Materials Conference II, Denver, CO, March 6-9, 1989.

\section{Theses}

C. J. Brannon, "An Investigation of the Low Voltage Failure Mechanism in Multilayer Ceramic Capacitors", M.S. Thesis, 1986.

R. Koc, "Struttural, Sintering and Conductivity Studies of the ( $\mathrm{La}, \mathrm{Sr}) \mathrm{Cr}(1-\mathrm{x}) \mathrm{Mn}_{\mathrm{x}} \mathrm{O}_{3}$ ", M.S. Thesis, 1986.

C. C. Chen, "Processing Study and Film Fabrication of Superconducting Y-Ba-Cu-O Ceramics", M.S Thesis, 1988.

J. D. Carter, "A Pushrod Type, Controlled Atmosphere Dilatometer for Thermal and Oxygen Activity Expansion Measurements", M.S Thesis, 1989. 


\section{MANUSCRIPTS PRESENTED, IN PREPARATION OR SUBMTTTED}

M. J. Pennell and H. U. Anderson, "Synthesis of Oxides Via an Ethylene Glycol Process", Am. Chem. Soc., Los Angeles, CA, Sept. 28, 1988.

H. U. Anderson, "Oxides for Fuel Cell Electrodes", Allied-Signal, Garrett Division, Los Angeles, CA, Sept. 28, 1988.

R. Koc and H. U. Anderson, "Structural, Sintering, and Electrical Properties of The PerovskiteType $(\mathrm{La}, \mathrm{Sr})(\mathrm{Cr}, \mathrm{Mu}) \mathrm{O}_{3}{ }^{\prime \prime}$, 41st Pacific Coast Meeting, Am. Cer. Suc., San. Francisco, CA, Oct. 25, 1988.

H. U. Anderson and D. M. Sparlin, "The Stability of $\mathrm{LaMnO}_{3}$ Under Fuel Cell Environments", ibid.

H. U. Anderson and M. J. Pennell, "Polymeric Synthesis of $\mathrm{LaMnO}_{3}$ and $\mathrm{LaCrO}_{3}$ ", ibid.

C. C. Chen and H. U. Anderson, "The Synthesis of $\mathrm{YBa}_{2} \mathrm{CuO}_{7-\mathrm{x}}$ Superconductor by the Ethylene Diamine Process", Industry-University Advanced Materials Conference, March 6-9, 1989, Denver, CO.

H. U. Anderson, "Fuel Cell Cathode and Interconnect Research at UMR", EPRI Solid Oxides Electrochemistry Workshop, Palo Alto, CA, Jan. 13, 1989.

R. Raffaelle, H. U. Anderson, D. M. Sparlin and P. Parris, "Conduction Mechanism in the $\mathrm{La}(\mathrm{Cr}, \mathrm{Mn}) \mathrm{O}_{3}$ Series", Am. Cer. Soc., Dallas, TX, April 1990.

R. Koc, H. U. Anderson and M. M. Nasrallah, "Effect of Processing and Dopants on Air Sinterable $\mathrm{LaCrO}_{3}{ }^{\prime \prime}$, ibid.

R. Koc and H. U. Anderson, "Low Temperature Sintering of $\mathrm{YCrO}_{3}$ and $\mathrm{LaCrO}_{3}$ Based Ceramics", Ceramic Powder Processing Science, San Diego, CA, Feb. 1990.

H. U. Anderson, C. C. Chen and J. C. Wang, "Synthesis of Conducting Oxide Films and Powders from Polymer Precursors, ibid.

S. Seward, G. Carini and H. U. Anderson, Structural, Sintering and Electrical Properties of the $\mathrm{YCrO}_{3}-\mathrm{YMnO}_{3}-\mathrm{YCOO}_{3}$ System", 1st International Symposium on Solid Oxide Fuel Cells, El. Chem. Soc., Hollywood, FL, Oct. 1989.

- R. Koc and H. U. Anderson, "An Sinterable $\mathrm{LaCrO}_{3}$ Based Ceramics", ibid.

J. H. Kuo, H. U. Anderson and D. M. Sparlin, "Oxidation-Reduction Behavior of Undoped and Sr Doped $\mathrm{LaMnO}_{3}$ : Defect Structure, Electrical Conductivity and Thermoelectric Powers", Sub. J. Solid State Chem.

M. M. Nasrallah and H. U. Anderson, "Acceptor/Donor Compensation in Rutile", Solid State Comm. 


\section{CURRENT AND PENDING SUPPORT}

Harlan U. Anderson

Current Support

Department of Energy - BES

"Characterization of the Redox Behavior and Stability of Electrically Conducting

Oxides", $\$ 140,000$

$7 / 1 / 88 \cdot 6 / 30 / 89$

DOE-METC

"Development of Improved Cathodes for Solid Oxide Fuel Cells", \$162,788

$2 / 1 / 89-1 / 31 / 90$

Pending

DOE - Equipment Proposal

"Acquisition of An Analytical Transmission Electron Microscope", \$290,590

$6 / 1 / 90$

NSF

"Role of Polymer Precursors and Improved Reliability of Electronic Ceramics, $\$ 451,199$

$6 / 1 / 90 \quad 3$ Years

Don Sparlin

Current Support

DOE - BES, (See Anderson) 


\section{CONTRIBUTORS TO PROGRAM}

\section{Students:}

1. Mr. R. Koc, Ceramic Engineering is a Ph.D. candidate studying the structural and sintering characteristics of the $\mathrm{LaCrO}_{3}-\mathrm{LaMnO}_{3}-\mathrm{LaCoO}_{3}$ system. He is supported by University funding. He completed his Ph.D. in December 1989.

2. Mr. G. Carini, Ceramic Engineering Ph.D. candidate, who is supported by this program. $\mathrm{He}$ is investigating the influence of cation stoichiometry and dopants on the $\mathrm{YCrO}_{3}$ $\mathrm{YMnO}_{3}$ system. He will receive his Ph.D. in May 1990.

3. Mr. C. J. Brannon, Ceramic Engineering Ph.D. worked on the super conducting oxides. He completed his Ph.D. in May 1989 and is nor 'employed by General Electric.

4. Mr. R. Raffaelle, Physics Ph.D. candidate, who is studying the conductivity of perovskite materials using effective medium theory. He is supported by this program and should complete his thesis by May 1990.

5. Mr. J. D. Carter is a Ceramic Engineering M.S. candidate who is developing our high temperature controlled atm. dilatometer. He is supported by this program and received. his M.S. degree in December 1989.

\section{OTHER CONTRIBUTORS TO PROGRAM}

1. Dr. H. U. Anderson, Curator's Professor of Ceramic Engineering and Senior Investigator, Materials Research Center, Principal Investigator and Program Director.

2. Dr. D. M. Sparlin, Professor of Physics, Co-investigator. His responsibilities are to perform the low temperature measurements on superconducting oxides, to supervise the DLTS program, and to assist with the electrical conductivity and Seebeck measurements. His years of experience in instrumentation are applied to the design of equipment and experiments for the general program.

3. Dr. J. Guha, Research Professor of Ceramic Engineering. His rcsponsibilities are to supervise and to assist in the preparation and characterization of samples. In addition, he provides considerable experience and guidance in the interpretation of phase equilibrium diagrams. 
4. Dr. P. E. Parris, Assistant Professor of Physics. He is modeling the conduction mechanisms in the chromite, manganite and cobaltite systems.

5. Dr. M. M. Nasrallah, Professor of Materials Science and Engineering at Cairo University in Cairo, Egypt, returned to our research group as a visiting professor in July 1989. He is assisting with experimental details and giving guidance in interpretation of results. 

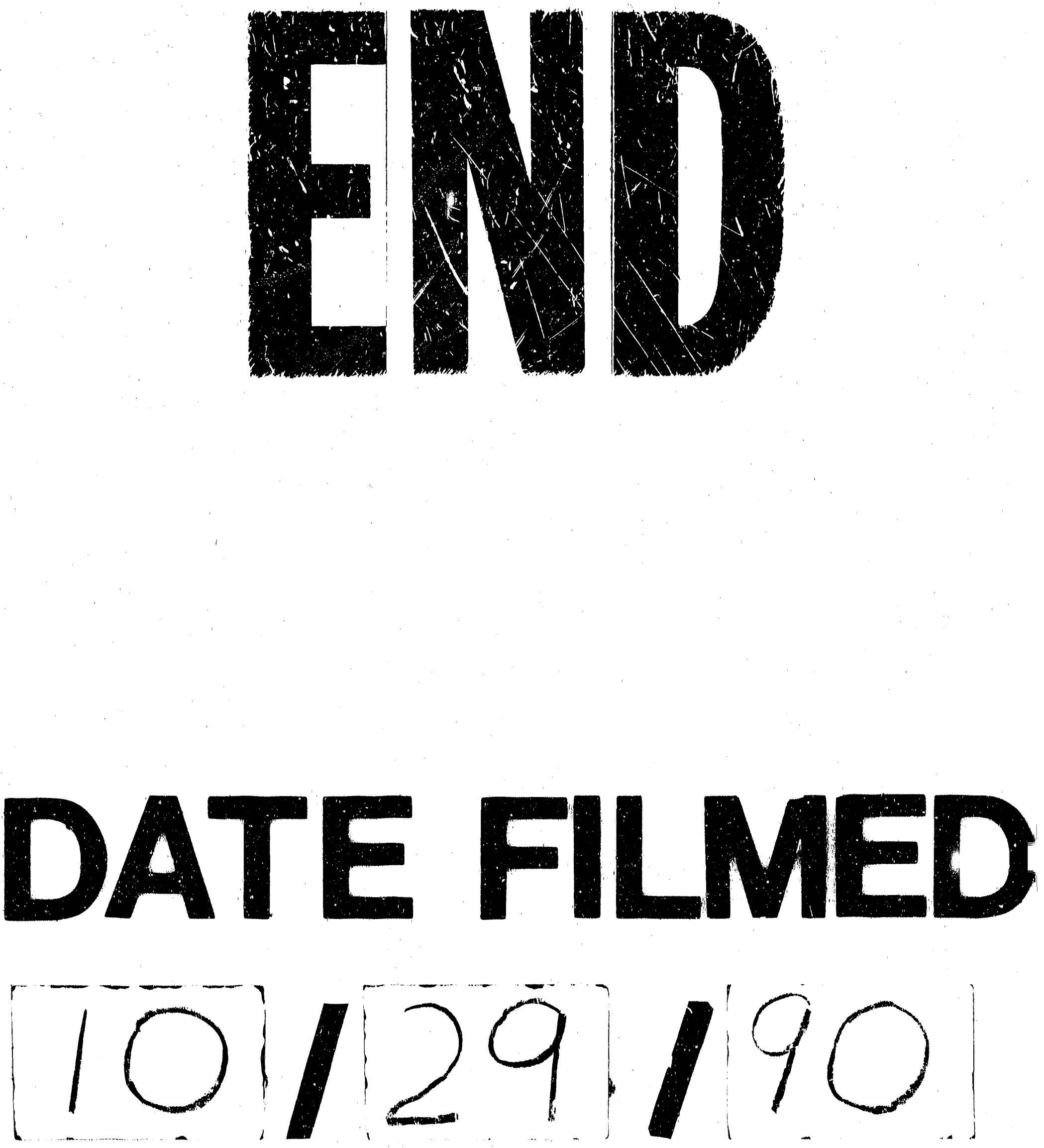
